\section{DIGITAL COMMONS \\ @ UNIVERSITY OF SOUTH FLORIDA}

\section{Revista Surco Sur}

\title{
La pasión por América en la poesía de Rubén Vela
}

Ime Biassoni

Follow this and additional works at: https://digitalcommons.usf.edu/surcosur

Part of the Latin American Languages and Societies Commons

\section{Recommended Citation}

Biassoni, Ime. 2011. La pasión por América en la poesía de Rubén Vela. Revista Surco Sur, Vol. 2: Iss. 3, 37-40.

DOI: http://dx.doi.org/10.5038/2157-5231.2.3.11

Available at: https://digitalcommons.usf.edu/surcosur/vol2/iss3/13

This NUESTRA AMÈRICA is brought to you for free and open access by the Open Access Journals at Digital Commons @ University of South Florida. It has been accepted for inclusion in Revista Surco Sur by an authorized editor of Digital Commons @ University of South Florida. For more information, please contact digitalcommons@usf.edu. 
En otoño de 1928 nace en la ciudad de Santa Fe, Argentina, Rubén Vela. En su niñez, en el campo, se van sumando las imágenes relacionadas con la tierra: el parral, las sombras proyectadas por la luna... aire, tierra y cielo... y además el mundo del campo del abuelo que le enseña a arar y sembrar, con sus peones, hacienda y reuniones nocturnas de historias y cuentos... Llanura, campo, fueron los primeros paisajes que marcarían a este multifacético poeta, con ideales claros y generoso humanismo.

Hijo de un eximio tenor del Teatro Colón, su juventud la vive en Buenos Aires. Allí se licenció en Antropología y Arqueología. Ya se vislumbraba en él que "las fronteras podían existir en la imaginación y estaba convencido de ser un argentino iberoamericano... ¡universalista!", al decir de la escritora Nidia Orbea, familiar de él (Sus abuelos eran hermanos). Su curiosidad y sentido de justicia social, lo llevaron a buscar una profesión que le permitiera conocer distintas culturas. Como diplomático vivió en Bolivia, Brasil, Austria, Alemania, España, Costa Rica, Corea y viajó por África. Las culturas indo americanas y africanas llamaron su atención.

Crítico literario y de arte, pero sobre todo poeta. Una carrera de más de treinta años en lo poético. Dice descubrir América a partir de su estadía en misión diplomática en Bolivia. ¿Por qué no antes? Esto se debió a que en Argentina, Chile, Uruguay, Brasil, Estados Unidos de Norteamérica, los nativos fueron casi exterminados, sobreviviendo algunos como "objeto de museo". En cambio en Bolivia, donde el poeta encuentra sus raíces americanas, lo mismo que en Perú, Ecuador, Paraguay, México y Guatemala, por su historia y evolución, pudieron hacer frente a la invasión, naciendo así una nueva cultura de mestizaje. En Argentina no fue posible porque las culturas autóctonas eran débiles.

Hasta entonces Vela era un ciudadano de Buenos Aires. Abierto a un panorama universal, de tradiciones y matices muy europeos, participando de las tertulias frecuentadas por Alberti, Casona, Margarita Xirgu, Baeza y otros grandes intelectuales del exilio español, pero desde que se enfrenta a esa "otra América" que se respira en un país como Bolivia, se le revela otro continente: de desolación, y misterio, una tierra dramática, exuberante, tan distinta de Europa, y de Buenos Aires, de marcada influencia europea. Allí analiza la otra parte: las raíces americanas, grandes modificadoras de nuestros pensamientos y dice: "A los europeos podemos enseñarles a ver lo suyo con ojos nuestros, con una mirada americana".

Su temática y simbología tienen una visión clara de las culturas premodernas, el Eros, la poesía antropológica, y se pega al ámbito que lo circunda como cuando dice en algunos de sus versos de "América":
Allí la tierra dio frutos
y el sol, hombres dorados.

Siempre sintió la necesidad de decir lo que lo rodeaba, conmovía, admirando la exaltación indígena de Vallejo, la pasión de Neruda y la musicalidad de Rubén Darío.

Autor de una ponencia que llevó a la restauración a las ruinas de Tiahuanaco.

El filósofo Mircea Eliade lo insta para que no describa América en su totalidad sino que la reconstruya a través de fragmentos. Entonces señala que no debe usar las formas literarias europeas. Cuando nombra las cosas es porque las crea. Así aparecen los vocablos: papa, maíz, papaya, melón, saltamontes, guanaco, hormiga, llama, lagartija...

Recorriendo otros países aparece el haikú y dice: "En las sociedades nuevas, como la nuestra, se toma al artista como un ser marginal. La labor del creador no está medida por la realidad de su 
obra, sino por su éxito. La poesía es una manera de luchar, sobre todo en América". Y aclara que el desarrollo cultural de un país depende de su economía. El Siglo de Oro español y la Literatura isabelina coincidieron con épocas de esplendor por su poderío. Sin embargo la poesía americana es hoy muy importante aunque no tenga toda la difusión por razones monetarias.

El sentido americanista de su obra es precursor en su generación, es búsqueda de su identidad:

Esto es América, me decían, mostrándome las altas cordilleras,

...Sólo vi pies descalzos, ...vi desolación. $\mathrm{Y}$, al borde, las grandes ciudades opulentas, sólo al borde...

Se despoja de lo superfluo llenándose de esta nueva Tierra que ya le circula por la sangre sin inflexión. Dice Juana Arancibia: En la síntesis y brevedad de sus "Fragmentos americanos", Vela evidencia su preocupación social y cito un poema compilador de la intuición total de la que surgió su libro Maneras de luchar:

Ella es América, un mutilado nombre, un cuerpo llagado y su cansancio.

Vela en América busca su propio rostro. Afloró siempre en él un sentimiento telúrico, revalorizando las culturas iberoamericanas. No existe "envoltorio retórico" en su poesía. Así lo muestra el siguiente poema de sólo dos versos, donde quedan representadas dos culturas americanas, la del norte con el maíz y la del sur con la papa:

Mi palabra es el maíz

Mi alimento es la papa helada.

Su economía verbal sacude, fusila, son pulsaciones poéticas:

He dicho América. La tierra abrió su piel.

Ya en su joven carrera aparecieron los grandes premios y sus poemas fueron traducidos al griego, inglés, alemán, italiano... Es que Vela, con sus símbolos y lenguaje, trasciende enarbolando la poesía de América, como Vallejo, como Neruda.

En La Ilíada se invocaron a los dioses. Vela quizás invoque a otros dioses... están Moctezuma, Viracocha, Machu Picchu, Tiahuanaco, Purmamarca, Pachamama, porque allí está nuestra madre América.

\section{Incendiarse}

en

la

palabra.

Crecer

en

libertad.

El poeta se incendia en vocablos simples, es que la abundancia de palabras ya fue dicha en silencio. Y como L. Marechal había comentado al referirse a Vela: "Está entre los pocos que hoy reivindican para la poesía el derecho y el deber de regresar al intelecto, hurtándose a las exclamaciones líricas de la mera sentimentalidad".

Pongo por ejemplo:

El

sol

dividiendo

su amor

al mediodía.

$\mathrm{Mi}$

futuro

incendiándose.

Rubén Vela

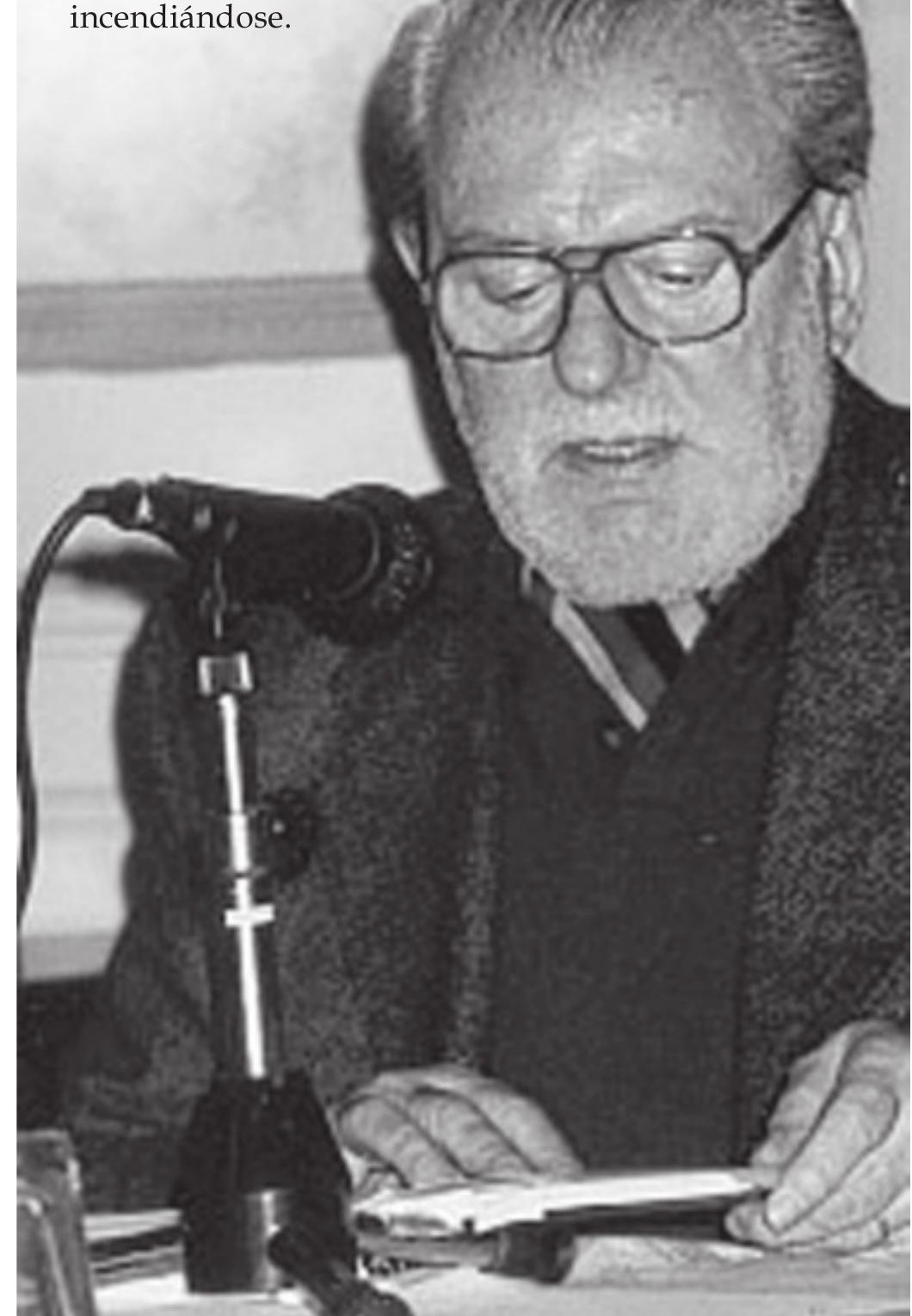




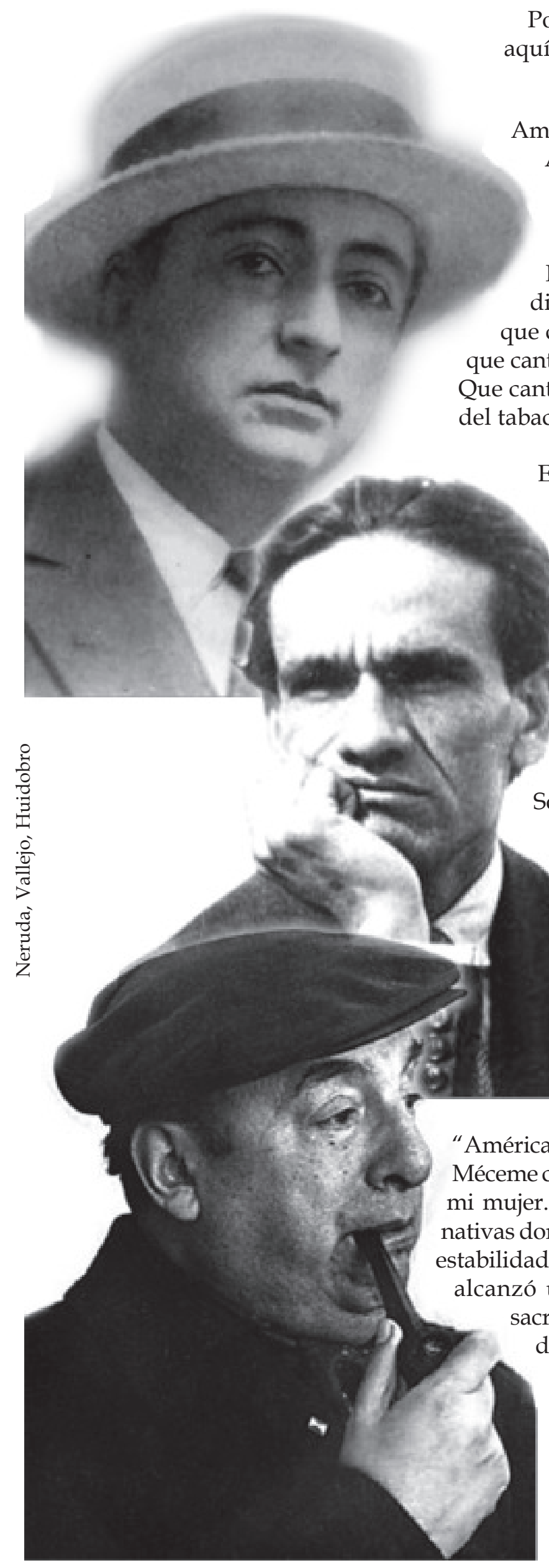

Poema de ocho versos y sólo diez palabras. Y he aquí del continente su:

\section{Definición}

América sin el Arco del Triunfo.

América sin el David de Miguel Ángel.

América sin la Venus de Ampurias.

Nueva e intacta América

que ignoraba la locura de Paolo Uccello.

Porque cuando digo América

digo la América que cantó Pablo Neruda,

que cantó el Cholo Vallejo

que cantó Huidobro como un nuevo maldito.

Que cantaron los hombres

del tabaco y la hechicería.

En este poema niega las contribuciones culturales europeas para afirmar los cantos de

Vallejo, Neruda y Huidobro. La civilización fue dañina para América, quemó su hechicería, su tabaco... no fue impertérrita. He aquí otro poema significativo en la voz de Vela:

"Esto es América" me decían,

mostrándome las altas cordilleras,

el suicidio del sol sobre los trópicos,

los grandes ríos furiosos.

Sólo vi pies descalzos,

criaturas americanas

sobre el hambre y el frío

como frutos desnudos.

Es la dualidad, los distintos bordes, por un lado la urbe con sus edificios invocando al cielo y por el otro la pobreza... y la tierra madre-mujer en su lucha... que da hijos y es parte del suelo, no quiere volar. El poeta identifica a América con la mujer: "América, / mujer total, / alimento y alojo / del hombre. Méceme como si fueras mi madre / Bésame como si fueras mi mujer..." Es el emblema de esa América con figuras nativas donde la piedra es, por su seguridad, permanencia, estabilidad... de la Tierra, testimonio, donde el continente alcanzó una identidad. Es la piedra de los antiguos sacrificios, la de los conflictos que seguirán tiñendo de sangre los enfrentamientos entre dos culturas en la conquista de occidente.

Es en esta Tierra fecunda en que los campesinos pasan a formar parte de los derredores de las ciudades, donde Vela manifiesta, con economía de palabras, pero seguro, la problemática social. Su protesta es el arma de la palabra. $\mathrm{Y}$ todo esto tiene que

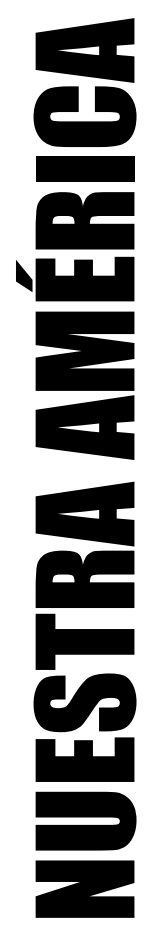


ver con su infancia, con su permanencia en distintas tierras, con la práctica de la meditación del Budismo Zen. Estos conocimientos de vida se transforman en metapoema.

Expresa en un reportaje que le hiciera Ceselli:

[...]tenemos que despojarnos de muchos valores culturales nocivos o inútiles. De tantas cosas accesorias que nos hemos echado encima. Tenemos que irnos abriendo como una cebolla. Y esto de la cebolla es precisamente el término que se emplea en arqueología para sacar capa por capa, la tierra que cubre la ruina. Parece una metáfora pero es la verdad. Tenemos que ir investigando dentro de nosotros por capas, como si fuera una cebolla, para poder descubrir lo que tenemos adentro.

Todo es un paso: ciencia, vida, amor... y afecta a ricos y pobres, sabios y necios y termina con la vejez y la muerte. Dice Cristina Pizarro: “Hay un ritmo de retorno como el sol que nace y muere cada día y esto está en la mitología de los Incas y también de los Mayas, lo mismo que en la China antigua y en la India". Existe una marcada orientación filosófica en sus poemas. "El amor a la sabiduría es expresión erótica. Según Platón Eros es el alma del mundo que vivifica el cosmos como un animal feliz".

Lo mismo que Gabriela Mistral, Pablo Neruda, Octavio Paz, Antonio de Undarraga y muchos otros de América y Europa, R. Vela fue un poeta viajero y un diplomático. De sus viajes y profesión surgen temas como Tiahuanaco, Machu Picchu, Chichén-Itzá, la Necrópolis de Paracas, la selva de Beni y figuras como Moctezuma, Viracocha, Caupolicán, Pachamama. Para Paz, América está en México. Para Vela es lo preincaico, lo Inca.

\section{Expresa Isaac Azofeifa:}

Uno está tentado de llamar a este poeta ( $R$. Vela), "poeta latinoamericano", sin más, como a Neruda, Vallejo, Darío, la Mistral y otros que han pasado hace tiempo a pertenecernos por igual a todos los que pensamos que América Latina es una sola Nación de naciones.
De esto se desprende que Vela no olvidó las vanguardias huidobrianas, los patetismos nerudianos, los misterios vallejianos, ni al metafísico Borges en su sur... Para él las viejas culturas andinas son el abrazo locuaz, las "memorias vegetales". Sus poemas son descarnados, dramáticos, enérgicos, apasionados y de un erotismo áspero.

Según Bella Jozef:

Esto no impide que la lectura del conjunto de sus poemas nos deje la impresión de un clima único, un denso tejido de alusiones. La sutilización del empleo de la imagen y de la metáfora, entronizados por el creacionismo y el surrealismo, y la depurada síntesis del poema aforístico - de que es ejemplo el haiku - lo hacen elegir el aspecto conceptual de la imagen, en versos de corte directo y conciso.

Para una mayor comprensión de su vivencia, apunto aquí lo siguiente: "Mi libertad consiste en que no me gusta la tierra redonda ni el nombre de Cristóbal Colón".

\section{Conclusiones}

En todo el universo poético de Rubén Vela, el poder de la piedra y su energía y el amor, asumen inmortalidad. Es que "sólo la piedra permanece"... Su poesía es vital y original. Decimos que sólo se puede llegar a ser un gran poeta cuando se es auténtico y cuando se llega a expresar poéticamente el Universo. Rubén Vela tiene las manos "llenas de poemas" quizás por ser un avaro del silencio, porque lo vive, y es allí donde nacen los poemas, dado que no concibe vivir sin la poesía.

Pero lo importante es su valor para mostrar nuestra América al mundo entero, desde nuestras

costumbres y fuerzas. Y como dice Forcat: "Supo trascender el horizonte de la época moderna y crear así una poesía de valor universal y permanente" 